\title{
Three New Species of the Genus Peptostreptococcus Isolated from Humans: Peptostreptococcus vaginalis sp. nov., Peptostreptococcus lacrimalis sp. nov., and Peptostreptococcus lactolyticus sp. nov.
}

\author{
NA LI, YASUHIRO HASHIMOTO, SHATHA ADNAN, HIROAKI MIURA, HIROYUKI YAMAMOTO, \\ AND TAKAYUKI EZAKI* \\ Department of Microbiology, Gifu University School of Medicine, Tsukasa-machi 40, \\ Gifu 500, Japan
}

\begin{abstract}
We describe three new species of the genus Peptostreptococcus which were isolated from human specimens and were tentatively identified as Peptostreptococcus prevotii. These three organisms were not homologous with previously described type strains of the genus Peptostreptococcus. A total of 12 strains that were identified biochemically as $P$. prevotii were divided into five independent DNA similarity groups; 10 of these strains were divided into three similarity groups which exhibited significant phenotypic differences from previously described species. Therefore, we propose the following new species: Peptostreptococcus vaginalis for group 1 strains, Peptostreptococcus lacrimalis for group 2 strains, and Peptostreptococcus lactolyticus for group 3 strains. The type strain of $P$. vaginalis is strain GIFU 12669 (= JCM 8138), the type strain of $P$. lacrimalis is strain GIFU 7667 (= JCM 8139), and the type strain of $P$. lactolyticus is strain GIFU 8586 (= JCM 8140).
\end{abstract}

Classification of members of the genus Peptostreptococcus has been evaluated by using both genetic and phenotypic methods $(3,5,7,8)$. However, in our identification work on anaerobic cocci by the microplate hybridization method (2), we found that many strains that were identified biochemically as Peptostreptococcus prevotii did not hybridize with the type strain of $P$. prevotii, strain ATCC 9321. Further investigation of these strains revealed that their DNAs did not hybridize with DNAs of previously described type strains of the genus Peptostreptococcus. Among the 12 strains whose DNAs did not hybridize with Peptostreptococcus DNAs, 10 strains were divided into three similarity groups which we were able to differentiate from previously described species by their phenotypic traits. In this paper we describe these strains and propose that they are members of independent species of the genus Peptostreptococcus.

\section{MATERIALS AND METHODS}

Strains and characterization. The strains used in this study are listed in Table 1. A total of 12 strains that were isolated from human clinical specimens were tentatively identified as $P$. prevotii by using conventional biochemical tests $(5,6)$. API ZYM and AN-IDENT tests (API, La Balme Les Grottes, Montalieu Vercieu, France) were also used to determine oxidase and peptidase activities. Bacterial strains were incubated on Columbia sheep blood agar plates at $37^{\circ} \mathrm{C}$ for $48 \mathrm{~h}$, and the cells were harvested for analysis of their enzyme activities.

Determination of cell wall peptidoglycan. Cells were subcultured in Gifu anaerobic medium (GAM; Nissui, Tokyo, Japan) broth and were incubated anaerobically at $37^{\circ} \mathrm{C}$ for 2 days. Cell walls were purified by using a previously de-

\footnotetext{
* Corresponding author.
}

scribed method $(9,10)$. Purified cell walls wẹre hydrolyzed with $6 \mathrm{~N}$ hydrochloric acid for $18 \mathrm{~h}$ at $100^{\circ} \mathrm{C}$ and were analyzed by using an amino acid analyzer.

Determination of base composition of DNA and quantitative DNA-DNA hybridization. G+C contents of DNAs were determined by using the high-performance liquid chromatography method described previously $(1,4,11)$. The DNADNA homology experiments were conducted in a microdilution plate as described previously (2). Hybridization was carried out in $2 \times$ SSC buffer $(1 \times \mathrm{SSC}$ is $0.15 \mathrm{M} \mathrm{NaCl}$ plus

TABLE 1. Butyrate-producing Peptostreptococcus strains used in this study

\begin{tabular}{|c|c|c|c|}
\hline $\begin{array}{l}\text { Name as determined } \\
\text { by biochemical tests }\end{array}$ & $\begin{array}{l}\text { GIFU } \\
\text { no. }\end{array}$ & $\begin{array}{c}\text { Other } \\
\text { designation }\end{array}$ & Source $^{a}$ \\
\hline P. prevotii & $7658^{\mathrm{T}}$ & $\operatorname{ATCC} 9321^{\mathbf{T}}$ & ATCC \\
\hline$P$. prevotii & $7667^{T}$ & JCM $8139^{\mathrm{T}}$ & Eye discharge \\
\hline$P$. prevotii & 7668 & & Eye discharge \\
\hline P. prevotii & 7714 & & Vaginal discharge \\
\hline P. prevotii & 7721 & & Vaginal discharge \\
\hline P. prevotii & 7752 & JCM 8141 & Umblicus smear \\
\hline P. prevotii & 7756 & & Umblicus smear \\
\hline P. prevotii & 8124 & JCM 8142 & Vaginal discharge \\
\hline P. prevotii & 8376 & & Vaginal discharge \\
\hline P. prevotii & $8586^{\mathrm{T}}$ & $\mathrm{JCM} 8140^{\mathrm{T}}$ & Vaginal discharge \\
\hline P. prevotii & 8587 & & Vaginal discharge \\
\hline P. prevotii & $12669^{T}$ & JCM $8138^{\mathrm{T}}$ & Ovarian abscess \\
\hline$P \cdot$ prevotii & 12670 & & Vaginal discharge \\
\hline P. asaccharolyticus & $7656^{T}$ & ATCC $14963^{\mathrm{T}}$ & ATCC \\
\hline P. hydrogenalis & $7662^{T}$ & & Human feces \\
\hline$P$. tetradius & $7672^{\mathrm{T}}$ & & Vaginal discharge \\
\hline$P$. indolicus & $7848^{\mathrm{T}}$ & ATCC $29427^{\mathrm{T}}$ & ATCC \\
\hline$P$. anaerobius & $7882^{\mathrm{T}}$ & ATCC $27337^{\mathrm{T}}$ & ATCC \\
\hline
\end{tabular}

${ }^{a}$ ATCC, American Type Culture Collection, Rockville, Md. 
TABLE 2. Guanine-plus-cytosine contents and DNA-DNA homology values for 18 strains of Peptostreptococcus species

\begin{tabular}{|c|c|c|c|c|c|c|c|c|c|c|c|c|c|c|}
\hline \multirow{3}{*}{$\begin{array}{l}\text { Name as determined } \\
\text { by biochemical tests }\end{array}$} & \multirow{3}{*}{$\begin{array}{l}\text { GIFU } \\
\text { no. }\end{array}$} & \multirow{3}{*}{$\begin{array}{l}\mathrm{G}+\mathrm{C} \text { content } \\
(\mathrm{mol} \%)^{a}\end{array}$} & \multicolumn{12}{|c|}{$\%$ Homology with labeled DNA from ${ }^{b}$ : } \\
\hline & & & \multicolumn{2}{|c|}{$\underset{7658^{\mathrm{T}}}{\text { Strain GIFU }}$} & \multicolumn{2}{|c|}{$\begin{array}{l}\text { Strain GIFU } \\
12669^{\mathrm{T}}\end{array}$} & \multicolumn{2}{|c|}{$\begin{array}{l}\text { Strain GIFU } \\
\quad 7667^{T}\end{array}$} & \multicolumn{2}{|c|}{$\begin{array}{l}\text { Strain GIFU } \\
{8586^{\mathrm{T}}}^{\mathrm{T}}\end{array}$} & \multicolumn{2}{|c|}{$\begin{array}{l}\text { Strain GIFU } \\
\quad 7752\end{array}$} & \multicolumn{2}{|c|}{$\begin{array}{c}\text { Strain GIFU } \\
8124\end{array}$} \\
\hline & & & $37^{\circ} \mathrm{C}$ & $45^{\circ} \mathrm{C}$ & $37^{\circ} \mathrm{C}$ & $45^{\circ} \mathrm{C}$ & $37^{\circ} \mathrm{C}$ & $45^{\circ} \mathrm{C}$ & $37^{\circ} \mathrm{C}$ & $45^{\circ} \mathrm{C}$ & $37^{\circ} \mathrm{C}$ & $45^{\circ} \mathrm{C}$ & $37^{\circ} \mathrm{C}$ & $45^{\circ} \mathrm{C}$ \\
\hline$P$. prevotii & $7658^{\mathrm{T}}$ & 34 & 100 & 100 & $-^{c}$ & - & - & - & - & - & - & - & - & - \\
\hline \multirow[t]{6}{*}{$P$. prevotii group 1} & $12669^{\mathrm{T}}$ & 30 & 32 & - & 100 & 100 & - & - & - & - & - & - & - & - \\
\hline & 7721 & 30 & - & - & 100 & 98 & $\mathrm{NT}^{d}$ & NT & NT & NT & NT & NT & NT & NT \\
\hline & 7756 & 29 & 30 & - & 100 & 95 & NT & NT & NT & NT & NT & NT & NT & NT \\
\hline & 12670 & 30 & - & - & 94 & 90 & NT & NT & NT & NT & NT & NT & NT & NT \\
\hline & 7714 & 29 & - & - & 90 & 89 & NT & NT & NT & NT & NT & NT & NT & NT \\
\hline & 8376 & 28 & - & - & 86 & 80 & NT & NT & NT & NT & NT & NT & NT & NT \\
\hline \multirow[t]{2}{*}{$P$. prevotii group 2} & $7667^{T}$ & 30 & - & - & 44 & - & 100 & 100 & - & - & - & - & - & - \\
\hline & 7668 & 31 & - & - & 32 & - & 100 & 95 & 43 & - & - & - & - & - \\
\hline \multirow[t]{2}{*}{$P$. prevotii group 3} & $8586^{\mathrm{T}}$ & 34 & - & - & 一 & - & - & - & 100 & 100 & - & - & - & - \\
\hline & 8587 & 34 & - & - & - & - & - & - & 86 & 79 & - & - & - & - \\
\hline$P$. prevotii group 4 & 7752 & 35 & - & - & - & - & - & - & - & - & 100 & 100 & - & - \\
\hline$P$ prevotii group 5 & 8124 & 40 & - & - & - & - & - & - & - & - & - & - & 100 & 100 \\
\hline$P$. tetradius & $7672^{\mathrm{T}}$ & 32 & 38 & - & - & - & - & - & - & - & - & - & - & - \\
\hline P. asaccharolyticus & $7656^{\mathrm{T}}$ & 32 & 一 & - & - & - & - & - & - & 一 & - & - & - & - \\
\hline$P$. hydrogenalis & $7662^{T}$ & 30 & - & - & 38 & - & - & - & - & - & - & - & - & - \\
\hline$P$. indolicus & $7848^{\mathrm{T}}$ & 34 & - & - & - & - & - & - & - & - & - & - & - & - \\
\hline$P$. anaerobius & $7882^{T}$ & 34 & - & - & - & - & - & - & - & - & - & - & - & - \\
\hline
\end{tabular}

${ }^{a}$ As determined by the high-performance liquid chromatography method.

${ }^{b}$ DNA-DNA hybridization experiments were carried out at $37^{\circ} \mathrm{C}$ (optimal conditions) and $45^{\circ} \mathrm{C}$ (stringent conditions) in $2 \times$ SSC containing $50 \%$ formamide. $c$, homology value less than $30 \%$.

${ }^{d}$ NT, not tested.

$0.015 \mathrm{M}$ sodium citrate) containing $50 \%$ formamide at 37 and $45^{\circ} \mathrm{C}$ for $2 \mathrm{~h}$.

\section{RESULTS}

G $+\mathbf{C}$ contents and DNA-DNA hybridization. The DNA base compositions of 12 strains and their homology values are shown in Table 2 . The $\mathrm{G}+\mathrm{C}$ content of $\boldsymbol{P}$. prevotii ATCC $9321^{\mathrm{T}}$ ( $\mathrm{T}=$ type strain) was determined to be $34 \mathrm{~mol} \%$ by the high-performance liquid chromatography method, and the $\mathrm{G}+\mathrm{C}$ contents of the 12 strains isolated from clinical specimens ranged from 28 to $40 \mathrm{~mol} \%$. The data obtained from DNA hybridization experiments are summarized in Table 2. DNA-DNA hybridization experiments revealed no similarity between the DNAs of these 12 strains and the DNA of $P$. prevotii ATCC $9321^{\mathrm{T}}$. The 12 strains isolated from clinical specimens were classified into five distinct similarity groups by using hybridization data.

Peptidoglycan type. From the molecular ratios of the amino acids we estimated the peptidoglycan types of the anaerobic cocci (Table 3). All 12 strains had D-glutamic acid as the interpeptide when cells were cultured in GAM broth, although both D-glutamic acid and D-aspartic acid were detected in members of similarity group 5 . The hydrolysate of strain GIFU $12669^{\mathrm{T}}$ contained both ornithine and lysine (molecular ratio, 1:0.83). The amino acids in positions 1 and 3 are shown in Table 3.

Biochemical characteristics. All 12 strains were stored in our culture collection as $P$. prevotii, since they produced butyric acid as a major metabolic product from peptoneyeast extract-glucose (PYG) medium and did not produce indole. Group 3 strains produced urease and fermented sugars. Thus, these strains are phenotypically related to Peptostreptococcus tetradius. $P$. prevotii ATCC $9321^{\mathrm{T}}$ and the 12 clinical strains were all negative in the indole test. In the urease test, $P$. prevotii ATCC $9321^{\mathrm{T}}$ and the group 3 strains were all positive. In carbohydrate fermentation tests, only group 3 strains fermented lactose and only group 4 strains fermented sucrose, whereas $P$. prevotii ATCC $9321^{\mathrm{T}}$ fermented neither lactose nor sucrose. Other characteristics are shown in Table 4. Differential characteristics for similarity groups 1 to 5 and previously described species are shown in Table 5.

\section{DISCUSSION}

Twelve strains that were isolated from clinical specimens and were previously identified as $P$. prevotii were genetically

TABLE 3. Peptidoglycan types of representative strains of the homology groups

\begin{tabular}{|c|c|c|c|c|}
\hline \multirow{2}{*}{ Taxon } & \multirow{2}{*}{$\begin{array}{c}\text { GIFU } \\
\text { no. }\end{array}$} & \multicolumn{3}{|c|}{ Cell wall peptidoglycan type ${ }^{a}$} \\
\hline & & Position 1 & Position 3 & Interpeptide \\
\hline$P$. prevotii & $7658^{\mathrm{T}}$ & Gly & Lys & D-Glu \\
\hline Group 1 & $12669^{\mathrm{T}}$ & Ala & Lys $(\text { Orn })^{b}$ & D-Glu \\
\hline Group 2 & $7667^{\mathrm{T}}$ & Ala & Orn & D-Glu \\
\hline Group 3 & $8586^{\mathrm{T}}$ & Gly & Lys & D-Glu \\
\hline Group 4 & 7752 & Ala & Orn & D-Glu \\
\hline Group 5 & 8124 & Ala & Orn & D-Glu (D-Asp) ${ }^{c}$ \\
\hline P. tetradius & $7672^{\mathrm{T}}$ & Gly & Lys & D-Glu \\
\hline P. asaccharolyticus & $7656^{\mathrm{T}}$ & Ala & Orn & D-Glu \\
\hline$P$. hydrogenalis & $7662^{T}$ & Ala & Lys & D-Glu \\
\hline$P$. indolicus & $7848^{\mathrm{T}}$ & Ala & Orn & D-Glu \\
\hline
\end{tabular}

a Ala, alanine; Gly, glycine; Orn, ornithine; Lys, lysine; D-Glu, D-glutamic acid; D-Asp, D-aspartic acid.

${ }^{b}$ The molecular ratio of Lys and Orn was 1:0.83.

c The molecular ratio of D-Glu and D-Asp was 1:1. 
TABLE 4. Biochemical characteristics of members of the five genetic groups and reference strains ${ }^{a}$

\begin{tabular}{|c|c|c|c|c|c|c|c|c|c|c|c|c|c|c|c|c|c|c|c|c|}
\hline \multirow{2}{*}{$\begin{array}{l}\text { Name as determined } \\
\text { by biochemical tests }\end{array}$} & \multirow{2}{*}{$\begin{array}{c}\text { GIFU } \\
\text { no. }\end{array}$} & \multicolumn{3}{|c|}{ Production of: } & \multicolumn{4}{|c|}{$\begin{array}{l}\text { Carbohydrate ferment- } \\
\text { ation }\end{array}$} & \multicolumn{4}{|c|}{ Saccharolytic enzymes } & \multicolumn{8}{|c|}{ Proteolytic enzymes } \\
\hline & & Indole & Jrease & ALP-ase & Glucose & Lactose & Maltose & Sucrose & e NPG & ADG & GAL $\beta$ & 3-GLU & LEU & ALA & HIS & GLY & PHA & INA & PRO & PYR \\
\hline$P$. prevotii & $7658^{\mathrm{T}}$ & $-b$ & + & + & $\mathbf{w}$ & - & $\mathbf{w}$ & - & - & + & + & w & + & + & + & + & + & + & - & + \\
\hline \multirow[t]{6}{*}{ P. prevotii group 1} & $12669^{\mathrm{T}}$ & - & - & + & w & - & w & - & - & - & - & - & + & + & + & + & - & - & - & - \\
\hline & 7714 & - & - & + & w & - & w & - & - & - & - & - & + & + & + & + & - & - & - & - \\
\hline & 7721 & - & - & + & w & - & $\mathbf{w}$ & - & - & - & - & - & + & + & + & + & - & - & - & - \\
\hline & 7756 & - & - & + & $\mathbf{w}$ & - & $\mathbf{w}$ & - & - & - & - & - & + & + & + & + & - & - & - & - \\
\hline & 8376 & - & - & + & w & - & $\mathbf{w}$ & - & - & - & - & - & + & + & + & + & - & - & - & - \\
\hline & 12670 & - & - & + & $\mathbf{w}$ & - & $\mathbf{w}$ & - & - & - & - & - & + & + & + & + & - & - & - & - \\
\hline \multirow[t]{2}{*}{ P. prevotii group 2} & $7667^{T}$ & - & - & - & - & - & - & - & - & - & - & - & + & + & + & + & + & - & - & - \\
\hline & 7668 & - & - & - & - & - & - & - & - & - & - & - & + & + & + & + & + & - & - & \\
\hline \multirow{2}{*}{$P$. prevotii group 3} & $8586^{\mathrm{T}}$ & - & + & + & + & + & + & - & + & - & - & - & + & + & + & + & - & - & - & + \\
\hline & 8587 & - & + & + & + & + & + & - & + & - & - & - & + & + & + & + & - & - & - & + \\
\hline P. prevotii group 4 & 7752 & - & - & - & - & - & - & - & - & + & + & - & - & + & + & + & + & $\mathbf{w}$ & - & \\
\hline$P$. prevotii group 5 & 8124 & - & - & - & - & - & - & - & - & - & $\mathbf{w}$ & - & - & + & + & + & - & - & - & - \\
\hline P. tetradius & $7672^{T}$ & - & + & - & + & - & + & + & - & + & ND & + & + & + & + & + & + & - & - & + \\
\hline$P$. asaccharolyticus & $7656^{\mathrm{T}}$ & + & - & - & - & - & - & - & - & - & - & - & - & - & - & - & - & $\mathbf{w}$ & - & - \\
\hline$P$. hydrogenalis & $7662^{T}$ & + & - & - & + & - & + & + & - & + & - & - & - & - & - & - & - & $\mathbf{w}$ & - & + \\
\hline$P$. indolicus & $7848^{\mathrm{T}}$ & + & - & - & - & - & - & - & - & - & - & - & + & + & + & + & $\mathbf{w}$ & - & - & - \\
\hline$P$. anaerobius & $7882^{\mathrm{T}}$ & - & - & - & + & - & + & - & - & + & - & - & - & - & - & - & - & - & + & - \\
\hline
\end{tabular}

${ }^{a}$ ALP-ase, alkaline phosphatase; NPG, $\beta$-galactosidase; ADG, $\alpha$-glucosidase; GAL, D-galactosidase; $\beta$-GLU, $\beta$-glucuronidase; LEU, leucine AMD; ALA alanine AMD; HIS, histidine AMD; GLY, glycine AMD; PHA, phenylalanine AMD; INA, indoxylacetate AMD; PRO, proline AMD; PYR, pyrrolidone AMD.

$b+$, positive $(\mathrm{pH}<5.5)$; - , negative $(\mathrm{pH}>6.0)$; $\mathrm{w}$, weakly positive $(5.5>\mathrm{pH}>6.0)$; $\mathrm{ND}$, not determined.

different from the type strain of $P$. prevotii, strain ATCC 9321. These 12 strains were classified into five distinct similarity groups, three of which were phenotypically different from previously described species. The results of a cell wall analysis also supported this observation. Only group 3 strains had a peptidoglycan type similar to that of $P$. prevotii and $P$. tetradius. Butyrate-positive peptostreptococci had D-glutamic acid as an interpeptide bridge of peptidoglycan (12). D-Aspartic acid and D-glutamic acid were detected in strain GIFU 8124, a member of similarity group 5. The $\mathrm{G}+\mathrm{C}$ contents of the 12 strains ranged from 28 to $40 \mathrm{~mol} \%$, although the $\mathrm{G}+\mathrm{C}$ content of $P$. prevotii ATCC $9321^{\mathrm{T}}$ was 33 to $34 \mathrm{~mol} \%$. Thus, these data also support the hypothesis that these 12 strains are heterogeneous.

Proposal of three new Peptostreptococcus species. Because strains belonging to groups 1 to 3 are phenotypically and genetically different from previously described species, we propose them as new species, as follows: Peptostreptococcus vaginalis for group 1 strains, Peptostreptococcus lacrimalis for group 2 strains, and Peptostreptococcus lactolyticus for group 3 strains. Although the strains belonging to groups 4 and 5 were differentiated by the DNA homology test, we had only one strain of each group, and the phenotypic characteristics of these organisms were not sufficient to differentiate them from previously described species. Thus, we will not propose them as new species until we acquire more strains belonging to these taxa and identify reasonable differentiating characteristics.

Description of Peptostreptococcus vaginalis sp. nov. Cells are strictly anaerobic, gram-positive cocci that occur in short chains or in masses. The strains produce alkaline phosphatase, but not urease, indole, or coagulase. Weak acid is produced from glucose and maltose, but not from lactose, cellobiose, sucrose, arabinose, ribose, mannitol, trehalose, sorbitol, and raffinose. The strains use peptone and oligopeptides as their major energy sources. Leucine arylamidase (AMD), alanine AMD, histidine AMD, and glycine AMD are present. The major metabolic products from GAM medium and PYG broth are butyrate and acetate. $P$. vaginalis was isolated from human vaginas. The $\mathrm{G}+\mathrm{C}$ contents of the DNAs of $P$. vaginalis strains are 28 to $30 \mathrm{~mol} \%$. The type strain is strain GIFU 12669 (= JCM 8138).

Description of Peptostreptococcus lacrimalis sp. nov. Cells are strictly anaerobic, gram-positive cocci that occur in short chains or in masses. Indole, coagulase, alkaline phosphatase, and urease tests are negative. No acid is produced from glucose, maltose, lactose, sucrose, mannitol, mannose, cellobiose, trehalose, raffinose, arabinose, ribose, and sorbitol. $\beta$-Glucuronidase and $\alpha$ - and $\beta$-galactosidases are not present. The strains use peptones and oligopeptides as their major energy sources. Leucine AMD, alanine AMD, histidine AMD, glycine AMD, and phenylalanine AMD are present. The major metabolic products from GAM medium and PYG broth are butyrate and acetate. $P$. lacrimalis was isolated from human eyes. The $\mathrm{G}+\mathrm{C}$ contents of the DNAs of the type strain and one other strain are 30 to $31 \mathrm{~mol} \%$. The type strain is strain GIFU 7667 (= JCM 8139).

Description of Peptostreptococcus lactolyticus sp. nov. Cells are strictly anaerobic, gram-positive cocci that occur in short chains or in masses. The strains produce urease, alkaline phosphatase, and $\beta$-galactosidase but not indole or coagulase. $\alpha$-Galactosidase, $\alpha$-glucosidase, and $\beta$-glucuronidase are not present. Strong acid $(\mathrm{pH}$ less than 5.5$)$ is produced from glucose, lactose, and maltose, but not from sucrose, mannitol, trehalose, sorbitol, and arabinose. The strains also have strong peptidase activity. Leucine AMD, alanine AMD, histidine AMD, glycine AMD, and pyrrolidone AMD are present. The major metabolic products from GAM broth and PYG medium are butyrate, lactate, and acetate. The pathogenicity of this organism is unknown. The $\mathrm{G}+\mathrm{C}$ content is $34 \mathrm{~mol} \%$. The type strain is strain GIFU 8586 (= JCM 8140).

Differential characteristics of $P$. vaginalis, $P$. lacrimalis, $P$. lactolyticus, and other Peptostreptococcus species are shown in Table 5. 


\section{REFERENCES}

1. Ezaki, T. 1982. Mole\% guanine plus cytosine of butyrateproducing anaerobic cocci and DNA-DNA relationship among them. Jpn. J. Bacteriol. 37:607-613.

2. Ezaki, T., Y. Hashimoto, and E. Yabuuchi. 1989. Fluorometric DNA-DNA hybridization in microdilution wells as an alternative to membrane filter hybridization in which radioisotopes are used to determine genetic relatedness among bacterial strains. Int. J. Syst. Bacteriol. 39:224-229.

3. Ezaki, T., S.-L. Liu, H. Hashimoto, and E. Yabuuchi. 1990. Peptostreptococcus hydrogenalis sp. nov. from human fecal and vaginal flora. Int. J. Syst. Bacteriol. 40:305-306.

4. Ezaki, T., S. M. Saidi, S.-L. Liu, Y. Hashimoto, H. Yamamoto, and E. Yabuuchi. 1990. Rapid procedure to determine the DNA base composition from small amounts of Gram-positive bacteria. FEMS Microbiol. Lett. 67:127-130.

5. Ezaki, T., H. Yamamoto, K. Ninomiya, S. Suzuki, and E. Yabuuchi. 1983. Transfer of Peptococcus indolicus, Peptococcus asaccharolyticus, Peptococcus prevotii, and Peptococcus magnus to the genus Peptostreptococcus and proposal of Peptostreptococcus tetradius sp. nov. Int. J. Syst. Bacteriol. 33: 683-698.

6. Holdeman, L. V., E. P. Cato, and W. E. C. Moore. 1977. Anaerobe laboratory manual, 4th ed. Virginia Polytechnic Institute and State University, Blacksburg.

7. Huss, V. A. R., H. Festl, and K. H. Schleifer. 1984. Nucleic acid hybridization studies and deoxyribonucleic acid base composition of anaerobic, gram-positive cocci. Int. J. Syst. Bacteriol. 34:95-101.

8. Moore, L. V. H., J. L. Johnson, and W. E. C. Moore. 1986. Genus Peptostreptococcus Kluyver and van Niel 1936, p. 1083-1092. In P. H. A. Sneath, N. S. Mair, M. E. Sharpe, and J. G. Holt (ed.), Bergey's manual of systematic bacteriology, vol. 2. The Williams \& Wilkins Co., Baltimore.

9. Schleifer, K. H., and O. Kandler. 1972. Peptidoglycan types of bacterial cell walls and their taxonomic implications. Bacteriol. Rev. 36:407-477.

10. Schleifer, K. H., and E. Nimmermann. 1973. Peptidoglycan types of strains of the genus Peptococcus. Arch. Mikrobiol. 93:245-258.

11. Tamaoka, J., and K. Komagata. 1984. Determination of DNA base composition by reversed phase high-performance liquid chromatography. FEMS Microbiol. Lett. 25:125-128.

12. Weiss, N. 1981. Cell wall structure of anaerobic cocci. Rev. Inst. Pasteur Lyon 14:53-59. 